\title{
Water Washing of Fungal-treated Carbonaceous Ores: Effect on Aurocyanide Adsorption by Activated Carbon in CIL Circuit*
}

\author{
${ }^{1}$ A. E. Adzigbli, ${ }^{1}$ G. Ofori-Sarpong, ${ }^{1}$ R. K. Amankwah \\ ${ }^{1}$ University of Mines and Technology, P. O. Box 237, Tarkwa, Ghana
}

Adzigbli, A. E., Ofori-Sarpong, G., and Amankwah, R. K., (2018), "Water Washing of Fungal-treated Carbonaceous Ores: Effect on Aurocyanide Adsorption by Activated Carbon in CIL Circuit", Ghana Mining Journal, Vol. 18, No. 1, pp. 65 - 71.

\begin{abstract}
A typical challenge encountered on most gold processing plants during leaching of refractory ores is the reduction in recovery due to the presence of carbonaceous matter which preg-robs dissolved gold. To reduce preg-robbing during cyanidation, carbonaceous matter has to undergo pretreatment to passivate the active surface. The fungus, Phanerochaete chrysosporium has been shown to biotransform carbonaceous matter, thus reducing its ability to preg-rob gold. However, the possible transfer of entrained fungal biomass into Carbon-In-Leach (CIL) circuits has been reported to decrease the activity of activated carbon, and a proposed solution to this was to wash the fungal-treated material thoroughly with water before CIL operation. This paper therefore set out to assess the effect of water-washing on aurocyanide adsorption by activated carbon in CIL following fungal pretreatment of carbonaceous ores. To realise the objective, activated carbon was contacted with cell-free extract of $P$. chrysosporium under varying conditions of $\mathrm{pH}$ and time, after which it was washed with different volumes of water, and its gold-adsorption ability assessed. The results revealed a decrease in the activity of activated carbon as a function of increasing contact time with the cell-free extract. The percentage decrease was higher after treatment in the acidic medium (13\%) than the basic medium (9\%). After washing the carbon (treated in acidic medium), gold adsorption was found to increase directly with the volume of water used from $64 \%$ at $0 \mathrm{~mL}$ to $84 \%$ at $500 \mathrm{~mL}$ and $91 \%$ at $1000 \mathrm{~mL}$. Correspondingly, the carbon treated in basic medium recorded $69 \%$ at $0 \mathrm{~mL}$ to $87 \%$ at $500 \mathrm{~mL}$ and $93 \%$ at $1000 \mathrm{~mL}$. This paper thus concludes that, sufficient water washing should be employed after fungal-biotransformation of refractory ores before CIL operation to decrease the effect of entrained biomass on the adsorption capacity of activated carbon.
\end{abstract}

Keywords: Carbonaceous Gold Ore, Activated Carbon, Carbon-In-Leach, Cell-Free Extracts

\section{Introduction}

Gold ores can be categorised based on metallurgical processes as refractory and nonrefractory. Refractory gold ores are ore types that are insusceptible to direct leaching by cyanide or simple gravity concentration. They can either be sulphidic, carbonaceous or double-refractory in nature. Gold associated with carbonaceous materials are preg-robbing. Carbonaceous material $(\mathrm{CM})$ in gold ores have been known to include charcoal, carbon, coal, shale, decaying wood, wood ashes and other vegetable matter. Natural CM in refractory carbonaceous gold ores behaves like activated carbon and adsorbs dissolved gold from solution (Adams et al., 1996; Rees and van Deventer 2000; Schmitz et al., 2001; Tan et al., 2003).

Refractory gold ores must necessarily undergo pretreatment processes so as to improve upon overall gold recovery. Mineralogy and other specific characteristics of refractory gold ores play a vital role when considering an appropriate technique for processing these gold ores. Bacterial oxidation of sulphide minerals is a familiar and commercially available process to enhance gold recovery with problem ores. Microbial pretreatment of refractory carbonaceous gold ores are gaining more attention presently as a potential replacement for other processes of pretreating methods such as roasting and surface blinding (Adams and Burger, 1998; Marsden and House, 2006). This is due to lower cost, less environmental issues, lower operating temperatures and the selfrejuvenating ability of the microorganisms employed (Marsden and House, 2006; OforiSarpong et al., 2010; 2017). The commercial bacterial oxidation process (BIOX), which has been used for about three decades now, however, encounters possible recovery challenges such as gold losses due to the presence of carbonaceous matter. This is because the bacteria used in the BIOX system are not able to deactivate the carbonaceous matter present in the gold ore (Amankwah et al., 2005; Madigan and Martinko, 2006; Ofori-Sarpong and Osseo-Asare, 2013; Ofori-Sarpong et al., 2013b; Adam et al., 2017).

Studies on different grades of carbonaceous matter in gold ores are normally done using different ranks of coal as surrogate due to the geological, structural and chemical similarities (Amankwah and Yen, 2006; Ofori-Sarpong et al., 2010; OforiSarpong and Osseo-Asare, 2013). Biotreatment of different grades of carbonaceous matter have been reported using various bacteria (Streptomyces setonii, Pseudomonas spp., Achcromobacter spp., Arthrobacter spp. and Rhodococcus spp) and fungi (Trametes versicolor, Aspergillus bruneiouniseriatus and Penicillium citrimum) (Brierley and 
Kulpa, 1993; Amankwah and Yen, 2006; Yen et al., 2008). Most of these researchers observed the highest degradation with bituminous-grade carbonaceous matter relative to the others.

Studies conducted on different ranks of coal have revealed that, anthracite has the highest capacity to preg-rob dissolved gold (Ibrado and Fuerstenau, 1992; Ofori-Sarpong et al., 2010), and anthracitegrade carbonaceous matter accounts for more than $50 \%$ of preg-robbing in gold processing (Stenebraten et al., 2000).

Ofori-Sarpong and Osseo-Asare (2013) therefore undertook a study that targeted on deactivating carbonaceous matter, and after treating lignite, bituminous and anthracite coals with the fungus, Phanerochaete chrysosporium, it was observed that, gold adsorption by anthracite decreased the most. Decrease in the ability of carbonaceous matter to preg-rob gold after fungal-treatment could be due to complete loss of carbon through the formation of carbon dioxide or the introduction of oxygen groups on the carbon leading to a disruption in the continuous nature of the graphitic planes required for adsorption. Other reasons assigned include coating of the carbon surface with fungal biomass, leading to deactivation by passivation (Helm et al., 2009; Ofori-Sarpong et al., 2013a; Qian et al., 2014).

Activated carbon is a carbonaceous material with a high degree of porosity and extended high surface area. Elemental carbon makes up more than $90 \%$ of activated carbon (Cecen, 2014). A major development in gold hydrometallurgy has been the industrial use of activated carbon for gold adsorption from alkaline cyanide leach solutions. Activated carbon is used to selectively concentrate dilute gold-bearing solutions to produce higher grade solution from which gold can be effectively extracted (Marsden and House, 2006). The gold is dissolved as $\mathrm{Au}(\mathrm{CN})_{2}{ }^{-}$complex and is recovered from the solution by Carbon-In-Pulp (CIP) or Carbon-In-Leach (CIL) processes (Bhattacharyya et al., 2014). In CIL operations, $25 \mathrm{~g} / \mathrm{L}$ of $\mathrm{AC}$ is currently applied on most free-milling gold processing plants (Marsden and House, 2006).

Activated carbon, intentionally introduced in CIL circuit to be used in recovery of dissolved gold from cyanide solution, is itself a carbonaceous matter in nature. When it is contacted with $P$. chrysosporium, there could be the possibility of surface deactivation of the carbon due to oxidation and/or coating by fungal biomass which serves as organic foulant (Helm et al., 2009; Ofori-Sarpong et al., 2013a; Qian et al., 2014; Bonnah et al., 2016). Carbonaceous gold ore biotreated with $P$. chrysosporium could carry along entrained fungal biomass into the CIL circuit, and this organic matter could have deactivating effect on the activated carbon. A study conducted by Bonnah et al., (2016) on the effect of fungal biomass on the adsorption of gold by activated carbon revealed that entrained biomass could reduce activated carbon adsorption by $18 \%-21 \%$ depending on $\mathrm{pH}$ and contact time.

These authors therefore recommended that feed from pretreatment process be washed thoroughly with water before entering the CIL circuit. Hence, the objective of this paper was to assess the effect of sufficient water washing on aurocyanide adsorption by activated carbon in CIL following fungal pretreatment of carbonaceous ores.

\section{Resources and Methods Used}

\subsection{Materials Used}

Materials used for the experimental work include fungal spores of Phanerochaete chrysosporium which was obtained from the Minerals Engineering Laboratory of the University of Mines and Technology, Tarkwa, pH modifiers (sodium hydroxide and sulphuric acid), activated carbon and gold solution, all from the Minerals Laboratory. Corn bran used as the growth media was obtained from a nearby Corn Mill Shop.

\subsection{Methods Employed}

The entire experiment was carried out in the Minerals Engineering Laboratory of the University of Mines and Technology, Tarkwa. The step by step procedures by which this work was done successfully include culturing of fungus, harvesting of cell-free extract after growth, conditioning of activated carbon, and contacting of cell-free extract with conditioned activated carbon. Gold solution of concentration $5 \mathrm{ppm}$ was used to conduct adsorption test on the various carbons. A control adsorption experiment was undertaken using asreceived, conditioned and unwashed treated carbons.

\subsubsection{Growth Medium Preparation, Culturing of Fungi and Harvesting of Cell-Free Extract}

Corn bran weighing $100 \mathrm{~g}$ each was transferred into five different PYREX Narrow Mouth Erlenmeyer Flasks, and $30 \mathrm{ml}$ of distilled water, added. Each flask was covered with aluminium foil and autoclaved at $121{ }^{\circ} \mathrm{C}$ for 30 mins to get rid of residual microorganisms. Upon cooling, fungi spores were introduced into the media at about 0.1 $\mathrm{g}$ per $100 \mathrm{~g}$ of corn bran. The cultures were allowed to grow at a temperature of $30^{\circ} \mathrm{C}$ for 10 days in an 
MRC Orbital Shaker Incubator. Oxygen was introduced into the culture by partially covering the flasks with a piece of foam as shown in Fig. 1. Fungal growth was assessed to be efficient after the incubation period by visual inspection.

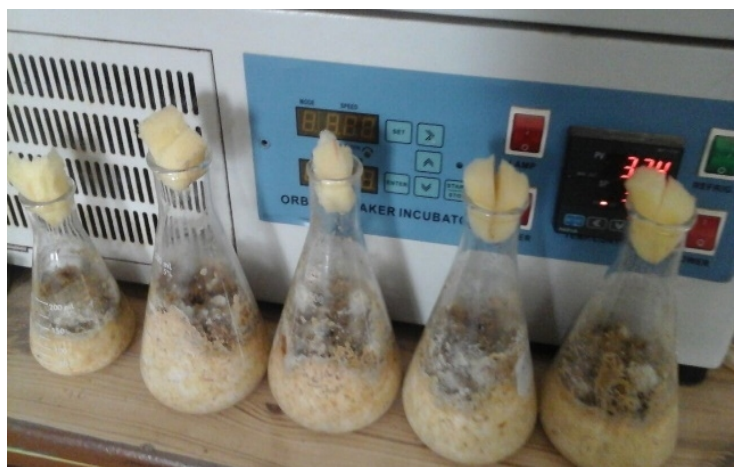

Fig. 1 A 10-day culture of $P$. chrysosporium

The biomass was removed from the culture after the incubation period, and the cell-free liquor extracted. This was done by pulping the entire media with $1.5 \mathrm{~L}$ of distilled water and sieving through quadruple-layered cheesecloth (OforiSarpong et al., 2013c) in order to separate the fungal biomass from the growth media. The $\mathrm{pH}$ of the cell-free extract was checked and recorded as 3.46 .

\subsubsection{Conditioning of Activated Carbon and Contacting with Cell-Free Extract}

Twelve beakers were set up to receive $1.25 \mathrm{~g}$ each of activated carbon and $30 \mathrm{ml}$ of distilled water, and the mixture left to soak for 10 mins to open up the pores of the activated carbon. The carbons were rinsed after the 10 mins conditioning period. The cell-free liquor extracted after the incubation period was divided into two and the initial $\mathrm{pH}$ increased from 3.46 to 4 on one hand, and 3.46 to 10.5 on the other hand using $\mathrm{NaOH}$ and $\mathrm{H}_{2} \mathrm{SO}_{4}$ as $\mathrm{pH}$ modifiers. The conditioned activated carbons were contacted with the cell-free extracts for varying time intervals $(2,4,8,12,24 \mathrm{hrs})$. They were then left in the incubator for the extract to interact with the activated carbon. At the end of each resident time, the activated carbon was rinsed with water.

\subsubsection{Rinsing of Treated Samples}

Samples treated with cell-free extract for 2, 4, 8 and 12 hours were rinsed with a constant volume of water $(200 \mathrm{ml})$ only to check the effect of treatment time on subsequent processes, whereas those treated for $24 \mathrm{hrs}$ were rinsed with various volumes of water ranging from $50 \mathrm{ml}$ to $1000 \mathrm{ml}$ to ascertain the effect of post-treatment washing on subsequent gold adsorption by activated carbon. The rinsing was done by putting the bottles on rollers to agitate. Table 1 shows the rinsing format for various contact times at $\mathrm{pH}$ of 4.0 and 10.5.

Table 1 Rinsing Format for Various Fungal Treatment Times (at $\mathrm{pH}$ of 4.0 and 10.5)

\begin{tabular}{|c|c|}
\hline $\begin{array}{c}\text { Fungal Treatment } \\
\text { Time (hrs) }\end{array}$ & $\begin{array}{c}\text { Volume of } \\
\text { water used (ml) }\end{array}$ \\
\hline 2 & 200 \\
\hline 4 & 200 \\
\hline 8 & 200 \\
\hline 12 & 200 \\
\hline 24 & 200 \\
\hline 24 & 50 \\
\hline 24 & 150 \\
\hline 24 & 300 \\
\hline 24 & 500 \\
\hline 24 & 750 \\
\hline 24 & 1000 \\
\hline
\end{tabular}

\subsubsection{Control Experiment}

The control experiment was set-up as follows:

(i) $1.25 \mathrm{~g}$ of the activated carbon (unconditioned) was contacted directly with $50 \mathrm{ml}$ of $5 \mathrm{ppm}$ gold solution to determine the adsorption rate of the carbon. This was labelled "as-received";

(ii) $1.25 \mathrm{~g}$ of the activated carbon was conditioned with water and contacted with $50 \mathrm{ml}$ of $5 \mathrm{ppm}$ gold solution to determine the adsorption rate of the carbon. This was labelled "as-received (conditioned)";

(iii) $1.25 \mathrm{~g}$ of the activated carbon was contacted with $50 \mathrm{ml}$ of cell-free liquor at $\mathrm{pH}$ of 4.0 for $24 \mathrm{hrs}$ but was not washed before contacting with the gold solution. This was labelled as "treated unwashed $(\mathrm{pH}$ 4.0 )"; and

(iv) $1.25 \mathrm{~g}$ of the activated carbon was contacted with $50 \mathrm{ml}$ of cell-free liquor at $\mathrm{pH}$ of 10.5 for $24 \mathrm{hrs}$ but was not washed before contacting with the gold solution. This was labelled as "treated unwashed $(\mathrm{pH}$ 10.5)".

\subsubsection{Contacting of Various Activated Carbons with Gold Solution}

A gold solution of concentration 5 ppm was prepared of which $50 \mathrm{ml}$ each was contacted with the various carbons for $24 \mathrm{hrs}$. After the $24 \mathrm{hr}$ resident time, loaded activated carbon was separated from the solution by filtration. The concentration of the residual gold solution was analysed using a Varian AA240FS Atomic Absorption Spectrometer (AAS). Results from AAS was analysed using Equations 1 and 2 respectively to determine the amount and 
percentage of aurocyanide adsorbed from solution. The adsorption capacities of the fungal-treated carbon were compared with the controls.

Adsorption $=$ Initial conc. - final conc.

$\%$ Adsorption $=\frac{\text { Adsorption }}{\text { Initial conc. }} \times 100 \%$

\section{Results and Discussion}

This paper aimed at ascertaining the effect of sufficient water washing of feed from pretreatment section to CIL, on aurocyanide adsorption by activated carbon. The effect of entrained biomass of $P$. chrysosporium on the adsorption capacity of activated carbon was analysed at $\mathrm{pH}$ of 4.0 and 10.5. Pretreatment times were varied as 2, 4, 8, 12 and 24 hours, and $200 \mathrm{ml}$ of fresh water was used to wash the fungal-treated carbons. In addition, samples treated for 24 hours were washed with various volumes of water ranging from $50 \mathrm{ml}$ to $1000 \mathrm{ml}$. The results obtained are presented and discussed in the ensuing sections.

\subsection{Gold Adsorption as a Function of Fungal Treatment Time at $\mathrm{pH}$ of 4.0 and $\mathbf{1 0 . 5}$}

Conditioned activated carbons treated with the cellfree extracts for $2,4,8,12,24 \mathrm{hrs}$ were washed with constant volumes of water $(200 \mathrm{~mL})$. The washed treated carbon was contacted with $50 \mathrm{ml}$ of gold solution. The amount of gold left in solution was read using an AAS. Fig. 2 illustrates the results of percentage adsorption with respect to biotreatment time at $\mathrm{pH}$ of 4 and 10.5 .

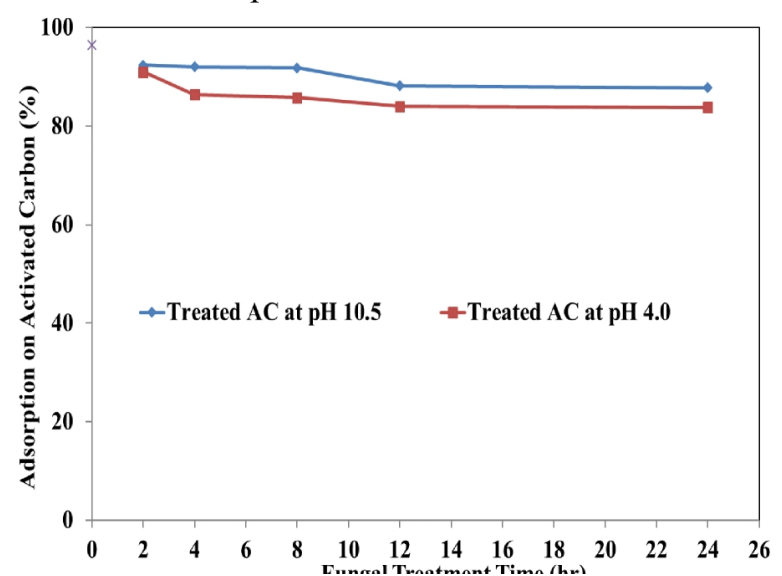

Fig. 2 Percentage Au Adsorption against Fungal Treatment Time at $\mathrm{pH} 4.0$ and 10.5

From Fig. 2, it was observed that, the percentage adsorption of aurocyanide complex onto activated carbon was generally low irrespective of the treatment $\mathrm{pH}$, though the values appeared to be lower after treatment in the acidic medium $(\mathrm{pH} 4.0)$ as compared with that of the basic medium $(\mathrm{pH}$ 10.5). This can be attributed to the fact that, $P$. chrysosporium grows better under conditions of relatively lower $\mathrm{pH}(2.0$ - 6.5) (Ofori-Sarpong et al., 2010; 2011), even though the fungus can survive over a wider range of $\mathrm{pH}$ (Andrawis et al., 1988; Ofori-Sarpong et al., 2017). The decrease in adsorption in both cases over the 24 hours confirms that entrained biomass of the fungi can cause significant damage to carbon activity in the CIL circuit (Bonnah et al., 2016).

In acidic medium ( $\mathrm{pH} 4.0$ ), percentage adsorption decreased from $91 \%$ at $2 \mathrm{hrs}$ through $84 \%$ at $12 \mathrm{hrs}$ and finally to $83.8 \%$ at the end of the 24 -hour period of contacting the conditioned activated carbon with the cell-free extract. General decrease in adsorption from the $2^{\text {nd }}$ hour of fungal treatment to the end of the $24^{\text {th }}$ hour treatment time was $7.91 \%$ for carbon treated with cell-free extract at $\mathrm{pH}$ of 4.0 and $4.98 \%$ for that treated at $\mathrm{pH} 10.5$. For the overall decrease in carbon activity at the end of the experiment, time 0 to 24 , a whopping $13 \%$ was recorded for $\mathrm{AC}$ treated at $\mathrm{pH} 4.0$ and $8.92 \%$ at $\mathrm{pH} 10.5$. It was concluded that biomass of $P$. chrysosporium in CIL circuit can cause significant decrease in carbon activity hence reducing overall gold recovery.

\subsection{Gold Adsorption as a Function of Volume of Water Used for Washing after Fungi Treatment at $\mathrm{pH}$ of 4 and 10.5}

Activated carbons treated at the same contact time (24 hrs) were washed with different volumes of water to analyse the effect of various volumes of water on its adsorption capacity. This was done for $\mathrm{pH} 4$ and 10.5. Activated carbon which was unwashed after contacting with cell-free extract and as-received (both unwashed and washed) activated carbon served as controls. These carbons were contacted with $50 \mathrm{ml}$ of gold solution. The amount of gold left in solution was read using AAS. Table 2 shows the initial condition and the percentage adsoption of the various carbons used as controls. 
Table 2 Initial Condition and Percentage Adsoption of Control Carbons

\begin{tabular}{|c|c|c|}
\hline Carbon & $\begin{array}{c}\text { Adsorption } \\
\text { on Activated } \\
\text { Carbon (\%) }\end{array}$ & $\begin{array}{c}\text { Volume of } \\
\text { Water Used } \\
\text { (ml) }\end{array}$ \\
\hline $\begin{array}{c}\text { As-received } \\
\text { (conditioned) }\end{array}$ & 96.4 & 0 \\
\hline $\begin{array}{c}\text { Treated but } \\
\text { unwashed, pH } \\
4.0\end{array}$ & 64.4 & 0 \\
\hline $\begin{array}{c}\text { Treated but } \\
\text { unwashed, pH } \\
10.5\end{array}$ & 68.6 & 0 \\
\hline As-received & 72.8 & 0 \\
\hline
\end{tabular}

Fig. 3 illustrates results of percentage adsorption with respect to volume of water used after treating the carbons at $\mathrm{pH}$ of 4.0 and 10.5.

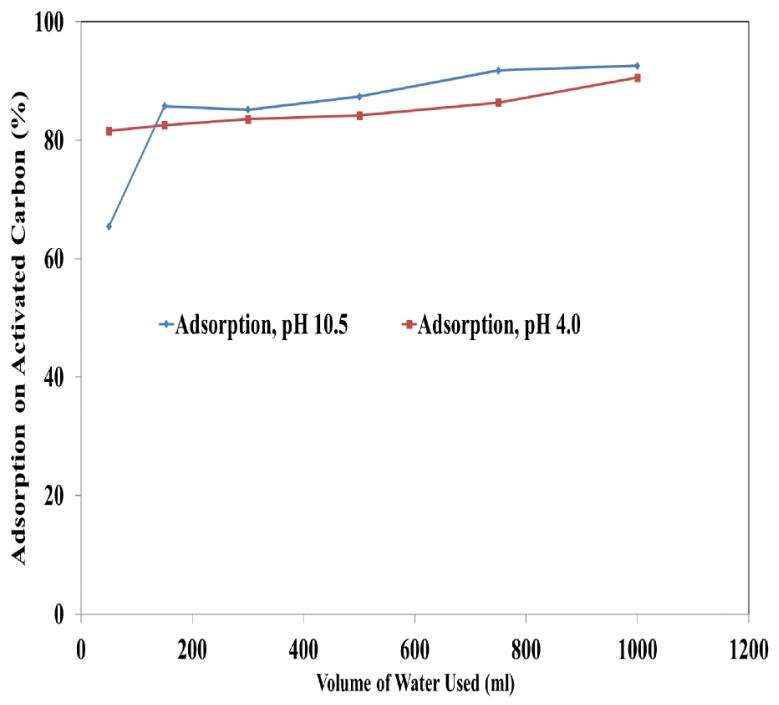

Fig. 3 Gold Adsorption against Volume of Water Used at pH 4.0 and 10.5

Considering gold adsorption at a $\mathrm{pH}$ of 4.0, after treating $1.25 \mathrm{~g}$ of activated carbon with $P$. chrysosporium for a straight $24 \mathrm{hr}$ period, gold adsorption increased gradually from $81.6 \%$ to $90.6 \%$ as the volume of water increased from $50 \mathrm{ml}$ to $1000 \mathrm{ml}$ as shown in Fig. 3. This is so because, sufficient water washing effectively removed entrained biomass which may have passivated the carbon and reduced its active site for adsorption (Ofori-Sarpong et al., 2013a). Referring from Fig. 3 , percentage adsorption was $81.6 \%$ when washed with $50 \mathrm{ml}$ of water; $83.6 \%$ when washed with 300 $\mathrm{ml}$ of water; and $90.6 \%$ when washed with $1000 \mathrm{ml}$ of water.

Comparing the percentage adsorption of $50 \mathrm{ml}$ $500 \mathrm{ml}$, an increment of $3 \%$ was realised, whereas $7 \%$ and $10 \%$ were realised for $500 \mathrm{ml}-1000 \mathrm{ml}$ and $50 \mathrm{ml}-1000 \mathrm{ml}$ respectively. Comparing the percentage adsorption of the treated but unwashed carbon to that washed with $50 \mathrm{ml}$ of water, $17.2 \%$ increase in adsorption was recorded. This implies that, washing the fungal-treated carbon with enough water can increase the adsorption capacity.

It was also observed that, the fungal-treated but unwashed carbon recorded a percentage adsorption of $64.4 \%$. Comparing this with the as-received (conditioned), percentage difference of $33.2 \%$ was observed. However, $11.5 \%$ increase in adsorption was recorded when the values of the fungal-treated but unwashed carbon was compared to the unconditioned as-received. This can be attributed to the fact that, as-received (conditioned) was rinsed before contacting with the gold solution which may have removed residual micro-organisms and dust particles present on the surface of the activated carbon (Marsden and House, 2006). Other reasons pertaining to this are subject to further investigation.

Making reference from Table 1 and Fig. 3, an increase in percentage adsorption from $68.6 \%$ (at 0 $\mathrm{ml}$ ) to $92.6 \%$ (at $1000 \mathrm{ml}$ ) resulted in the case of gold adsorption after treatment at a $\mathrm{pH}$ of 10.5. A $25.2 \%$ increase in adsorption was observed when the values of carbon washed with $50 \mathrm{ml}$ and $500 \mathrm{ml}$ of water were compared whereas $6 \%$ and $42 \%$ were observed for $500 \mathrm{ml}-1000 \mathrm{ml}$ and $50 \mathrm{ml}-$ $1000 \mathrm{ml}$ respectively, meaning, washing the fungal-treated carbon with enough water can increase the adsorption capacity of the carbon as also established in the acidic medium.

An adsorption percentage of $72.8 \%$ was recorded for the as-received activated carbon and this is relatively low as compared with as-received (conditioned). This may be associated with the fact that the as-received carbon was not conditioned, and hence may have dust particles and residual micro-organisms settling on the carbon surface and blocking the active sites of the activated carbon. This suggests even as-received activated carbon should be washed before introduced into CIL for gold adsorption.

In general cases (both $\mathrm{pH} 4.0$ and $\mathrm{pH}$ 10.5), sufficient water washing improved on the recovery of aurocyanide from solution onto the activated carbon.

\section{Conclusions and Recommendations}

The main objective of this research was to assess the effect of sufficient water washing on aurocyanide adsorption by activated carbon in CIL following fungal pretreatment of carbonaceous ores. In relation to this, activated carbon treated for 
$2,4,8,12$ were washed with $200 \mathrm{ml}$ of water, whereas those treated for $24 \mathrm{hrs}$ were contacted with various volumes of water ranging from $50 \mathrm{ml}$ to $1000 \mathrm{ml}$. In assessing the effect of activated carbon contact time with cell-free extract, overall decrease in the carbon's activity from time 0 to 24 hrs was a whopping $13 \%$ recorded at $\mathrm{pH} 4.0$ and $9 \%$ at $\mathrm{pH} 10.5$. In relation to this, it can be deduced that, the presence of the fungal biomass in the CIL circuit has deactivating effect on activated carbon, and this increases with increasing fungal-treatment time. The effect of $P$. chrysosporium appeared to be more pronounced in acidic medium than basic medium since the fungi is more active in lower $\mathrm{pH}$ range.

After washing the carbons with various volumes of water, the percentage adsorption gradually increased from $62 \%$ to $91 \%$ for the acidic medium and $64 \%$ to $93 \%$ for the basic medium. This represents about $29 \%$ increase in both cases. It was therefore concluded that, sufficient water washing decreases the effect of entrained biomass on the adsorption capacity of activated carbon. Further research is being done using real carbonaceous materials treated with $P$. chrysosporium, and assessing the impact of entrained biomass on activated carbon adsorption. In the meantime, it is recommended that pretreated materials should be washed with sufficient water before CIL operations.

\section{References}

Adam, A. S., Ofori-Sarpong, G. and Amankwah, R. K., (2017), "Assessing the Challenges in the Extraction of Gold from Bacterial-Treated Double-Refractory Concentrate", SME Annual Meeting, Denver, USA, pp. 1-7.

Adams, M. D., Burger, A. M., 1998. "Characterization and blinding of carbonaceous preg-robbers in gold ores", Minerals Engineering 11 (10), pp. 919-927.

Adams, M. D., Swaney, S. J., Fried, J. and Wagner, F.E., (1996), "Preg-robbing Minerals in Gold ores and residues", Hidden Wealth. S. African, Inst. Min. and Metall., Johannesburg, pp. 163172.

Amankwah, R. K. and Yen, W. T. (2006), "Effect of carbonaceous characteristics on biodegradation and preg-robbing behaviour", In: Onal, G., Acarkan, N., Celik, M. S., Arslan, F., Atesok, G., Guney, A., Sirkecl, A. A., Yuce, A. E., Perek, K. T. (Eds.), Proceedings of the 23rd International Mineral Processing Congress, Promed Advertising Limited, Instanbul, pp. 1445-1451.

Amankwah, R.K., Yen, W.T. and Ramsay, J. (2005), "A Two-Stage Bacterial Pretreatment
Process for Double Refractory Gold Ores", Minerals Engineering, Vol. 18, pp. 103-108.

Andrawis, A., Johnson, K. A. Tien, M., (1988), "Studies on Compound I Formation of the Lignin Peroxidase from Phanerochaete chrysosporium", The Journal of Biological Chemistry, Vol. 3, pp. 1195-119.

Bhattacharyya, D., Depci, T., Elnathan, F. and Miller, J.D. (2014), "Effect of Activated Carbon Particle Size on The Adsorption/Desorption of Gold from Alkaline Cyanide Solution", SME Annual Meeting, SME, Salt Lake City, 3 pp.

Bonnah, R. C., Ocran, B., Diko, C. S. and OforiSarpong, G. (2016), "Effect of Fungal Treatment on Gold Adsorption by Activated Carbon -A Preliminary Study", 4th UMaT Biennial International Mining and Mineral Conference, Tarkwa, Ghana, pp. 189-194.

Brierley, J. A., Kulpa, C. F., 1993. Biometallurgical treatment of precious metal ores having refractory carbon content. US Patent, 5, p. 244,493.

Cecen, F. (2014), “Activated Carbon", www.researchgate.net/publication/263062486. Assessed: 17th February, 2017.

Helm, M., Vaughan, J., Staunton, W.P., and Avraamides, J. An investigation of the carbonaceous component of preg-robbing gold ores. World Gold Conference 2009, The Southern African Institute of Mining and Metallurgy, 2009.

Ibrado, A. S., Fuerstenau, D.W. (1992), "Effect of the structure of carbon adsorbents on the adsorption of gold cyanide", Hydrometallurgy, Vol. 30, pp. 243-256.

Madigan, M. T., Martinko, J. M., 2006. Brock's biology of microorganisms, $11^{\text {th }} \mathrm{ed}$., Pearson Prentice Hall, Upper Saddle River, NJ, pp. 469472, 691-692.

Marsden, J. and House, I., 2006. The chemistry of gold extraction, $2^{\text {nd }}$ ed., Society for Mining, Metallurgy and Exploration, Inc. Littleton, Colorado, pp. 42-44, 111-126, 161-177, 191193, 233-263, 297-333.

Ofori-Sarpong, G. and Amankwah, R.K., OsseoAsare, K. (2013a), "Reduction of Preg-Robbing by Biomodified Carbonaceous Matter-A Proposed Mechanism", Minerals Engineering, Vol. 42, pp. 29-35.

Ofori-Sarpong, G. and Osseo-Asare, K. (2013), "Preg-robbing of Gold from Cyanide and NonCyanide Complexes: Effect of Fungi Pretreatment of Carbonaceous Matter", International Journal of Mineral Processing, Vol. 119, pp. 27-33.

Ofori-Sarpong, G., Osseo-Asare, K., Osei, R. and Amankwah, R. K. (2017), "Assessing the Parameters for Optimum Biotransformation of Carbonaceous Matter by Phanerochaete chrysosporium" Advances in Bioscience and 
Bioengineering, Vol. 5, No. 6, pp. 107-114. doi: 10.11648/j.abb.20170506.13.

Ofori-Sarpong, G., Osseo-Asare K., and Tien, M. (2013b), "Mycohydrometallurgy: Biotransformation of Double Refractory Gold Ores by the Fungus, Phanerochaete chrysosporium", Hydrometallurgy, Vol. 137, pp. 38 - 44.

Ofori-Sarpong, G., Osseo-Asare K, and Tien, M (2013c), "Pretreatment of Refractory Gold Ores using Cell-Free Extracts of Phanerochaete chrysosporium: a Preliminary Study", Advanced Materials Research, Vol. 825, pp. 427-430.

Ofori-Sarpong, G., Osseo-Asare K., and Tien, M. (2011), "Fungal biotransformation of anthracitegrade carbonaceous matter: Effect on gold cyanide uptake", In: Biohydrometallurgy: Biotech key to unlock mineral resources value, Proceedings of the 19th International Biohydrometallurgy Symposium, Qiu, G., Jiang, T., Qin, W., Liu, X., Yang, Y. and Wang, H. (Eds.), Vol. 1, Central South University Press, Changsha, China, pp. 445-451.

Ofori-Sarpong, G., Tien, M., Osseo-Asare, K. (2010), "Myco-hydrometallurgy: Coal model for potential reduction of preg-robbing capacity of carbonaceous gold ores using the fungus, Phanerochaete chrysosporium", Hydrometallurgy 102, 66-72.

Qian LIU, Hong-ying YANG, Lin-lin TONG (2014), "Influence of Phanerochaete chrysosporium degradation and preg-robbing capacity of activated carbon", Trans. Nonferrous Met. Soc. China, pp. 1905-1911.

Rees, K.L. and Van Deventer, J. S. J. (2000), "Preg-robbing Phenomena in the Cyanidation of Sulphide Gold Ores", Hydrometallurgy, Vol. 58, pp. 61-80.

Schmitz, P.A., Duyvesteyn, S., Johnson, W.P., Enloe, L., McMullen, J., 2001. Adsorption of aurocyanide complexes onto carbonaceous matter from preg-robbing Goldstrike ore. Hydrometallurgy 61, 121-135

Stenebraten, J. F., Johnson, W. P., McMullen, J., (2000), "Characterization of Goldstrike Ore" Carbonaceous Material Part 2, Minerals and Metallurgical Processing 17, pp. 7-15.

Tan, H., Feng, D. and Van Deventer, J. S. J. (2003), "Effect of carbonaceous coatings on preg-robbing of chalcopyrite", Proceedings Hydrometallurgy 2003 - Fifth International Conference, Young, C.A., Alfantazi, A.M., Anderson, C.G., Dreisinger, D.B., Harris, B. and James, A. (Eds), Pennsylvania, U.S.A, pp. $35-48$.

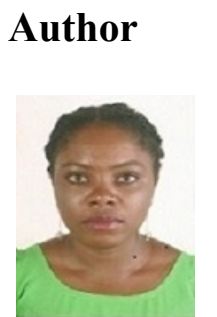

Abigail Ewoenam Adzigbli is currently a National Service Person at Kinross-Chirano Gold Mine. She holds a BSc in Minerals Engineeering from the University of Mines and Technology, Tarkwa, Ghana (UMaT). She interned as a laboratory technician in the Minerals Engineering Labouratory of UMaT. Her research interests are in mycohydrometallurgy, extraction of precious minerals, environmental and safety and mineral processing. She is a member of the South African Institute of Mining and Metallurgy (SAIMM).

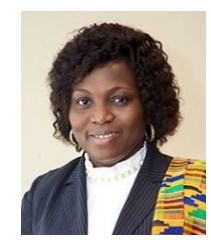

Grace Ofori-Sarpong is an Associate Professor of Minerals Engineering at the University of Mines and Technology, Tarkwa. She holds a PhD in Energy and Mineral Engineering from the Pennsylvania State University, an MSc in Environmental Resources Management and $\mathrm{BSc}$ in Metallurgical Engineering, both from the Kwame Nkrumah University of Science and Technology, KNUST, Kumasi, Ghana. Her areas of research interest include microbial-mineral interaction, water quality monitoring, acid mine drainage issues, microwaves in extractive metallurgy, bio-modification of recalcitrant organic matter and small-scale gold mining. She is a member of the Society for Mining, Metallurgy and Exploration Engineers (SME), Society of Petroleum Engineers (SPE), Women in Mining (WiM) and the West African Institute of Mining, Metallurgy and Petroleum (WAIMM)

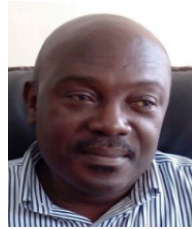

Richard K Amankwah is a Professor of Minerals Engineering at the University of Mines and Technology (UMaT), Tarkwa, Ghana. He holds a PhD degree in Mining Engineering from Queen's University, Canada, and MPhil and BSc in Metallurgical Engineering from the Kwame Nkrumah University of Science and Technology, KNUST, Kumasi, Ghana. His research interests include gold beneficiation, water quality management, microwave processing of minerals, smallscale mining, medical geology, microbial mineral recovery and environmental biotechnology. He is a Fellow of the West African Institute of Mining, Metallurgy and Petroleum (WAIMM), a member of the Ghana Institution of Engineers and the Society for Mining, Metallurgy and Exploration Engineers (SME). 